Z Badań nad Książką i Księgozbiorami Historycznymi 2019. T. specjalny: Dla Niepodległej The Studies into the History of the Book and Book Collections 2019. Special issue: For an Independent Poland

Alicja Maślak-Maciejewska

https://doi.org/10.33077/uw.25448730.zbkh.2020.195 Uniwersytet Jagielloński w Krakowie alicja.maslak@uj.edu.pl ORCID 0000-0002-2164-0344

\title{
XIX-wieczne czytelnie krakowskich Żydów postępowych
}

\author{
Abstract \\ Reading Rooms of progressive Jews in Krakow \\ in the $19^{\text {th }}$ century
}

The article discusses activities of two Reading Rooms which were created in the milieu of the progressive Jews in Krakow, Galicia in the $19^{\text {th }}$ century: The Israelite Reading Room (1871) and The Reading Room of the Jewish Merchant Youth (1882). Both Reading Rooms fostered not only readership but also social integration, education, and became centers of Polish patriotism. They contributed to the development of Jewish publish libraries.

Key words: Jewish Reading Room - Progressive Synagogue - Tempel, modernization - Jewish inteligentsia.

Słowa kluczowe: Czytelnia żydowska - synagoga postępowa - Tempel, modernizacja inteligencja żydowska.

„Z Badań nad Książką i Księgozbiorami Historycznymi” - Udział zagranicznych recenzentów w ocenie publikacji; Stworzenie anglojęzycznej wersji wydawniczej publikacji; Digitalizacja tomów archiwalnych rocznika w celu zapewnienia otwartego dostępu do nich przez Internet oraz wdrożenie i utrzymanie cyfrowej platformy redakcyjnej - zadanie finansowane w ramach umowy nr 653/P-DUN/2019 ze środków Ministra Nauki i Szkolnictwa Wyższego przeznaczonych na działalność upowszechniającą naukę. 
Żydzi postępowi to grupa związana z synagogą postępową (Tempel), stanowiąca kilka procent żydowskiej społeczności Krakowa. Jej członkowie rekrutowali się z trzech głównych warstw społeczno-zawodowych - inteligencji, kupiectwa oraz osób utrzymujących się z własności (np. zakładu produkcyjnego czy nieruchomości). Byli więc grupą relatywnie zamożną i dobrze wykształconą, a wielu spośród jej przedstawicieli skończyło świeckie szkoły średnie oraz studia akademickie. Organizacją, która zrzeszała Żydów postępowych było istniejące od lat 40. XIX w. Stowarzyszenie Izraelitów Postępowych (nazwa zmieniała się kilkakrotnie, w pierwszych dekadach istnienia organizacji była niemiecka). Głównym zadaniem Stowarzyszenia było utrzymanie synagogi postępowej, a przed jej założeniem (1861 r.) prywatnego domu modlitwy, gdzie odbywały się zmodernizowane nabożeństwa ${ }^{1}$.

Żydzi postępowi byli w XIX w. wyraźnie obecni na krakowskim rynku książki, chociaż nie można powiedzieć, że na nim dominowali. Kilku z nich było znanymi księgarzami (np. Israel Z. Herzog) prowadziło drukarnię (np. Józef Fischer), lub wypożyczalnię książek (np. Abraham Gumplowicz)². Mimo iż przynajmniej części spośród tych instytucji nie można odmówić pewnego aspektu ideowego i chęci wpływu na ogólny poziom wykształcenia społeczności żydowskiej, były one przede wszystkim przedsięwzięciami komercyjnymi. Ich podstawowym celem, nawet jeśli nie jedynym, było generowanie zysku.

Środowisko postępowe miało duży wpływ na powstanie pierwszych w Krakowie świeckich czytelni żydowskich - Czytelni Izraelickiej oraz Czytelni Starozakonnej Młodzieży Handlowej. Ich działalność, przynajmniej częściowo, była skierowana do szerszych grup społecznych. Jako takie położyły podwaliny pod późniejszy rozwój bibliotek publicznych, na czele z krakowską Biblioteką Judaistyczną „Ezra”, jedną z najsłynniejszych świeckich bibliotek żydowskich na ziemiach polskich. Celem niniejszego artykułu jest omówienie działalności tych stosunkowo mało znanych dziś instytucji ${ }^{3}$.

1 Więcej na temat tego stowarzyszenia, jego historii, liczebności, struktury zawodowej członków piszę w książce Modlili się w Templu. Krakowscy Żydzi postępowi w XIX wieku - studium społeczno-religijne, Kraków 2018.

2 O wypożyczalni Gumplowicza zob. H. Kozińska-Witt, Die Krakauer Jüdische Reformgemeinde 1864-1874, Frankfurt am Main 1999, s. 52. J. Fisher (kantor krakowskiego Templa) posiadal zarówno wypożyczalnię książek, jak i bardzo prężnie działającą drukarnię. Jak pisał Henryk Halkowski „W okresie przed pierwszą wojną światową była to zapewne najważniejsza hebrajska drukarnia i wydawnictwo na świecie”, zob. tenże, Żydowski Kraków. Legendy i ludzie, Kraków-Budapeszt 2009, s. 280.

3 Mimo iż działalność czytelni będących przedmiotem niniejszego artykułu nie doczekała się szerszego opracowania, pewne informacje na ich temat pojawiają się w literaturze przedmiotu. Najistotniejszym opracowaniem jest artykuł K. Samsonowskiej, Żydowskie biblioteki i czytelnie w Krakowie w XIX i XX wieku, „Rocznik Biblioteki Polskiej Akademii Nauk w Krakowie” 1998, t. 43, s. 219-232; zob. także A. Żbikowski, Żydzi krakowscy i ich gmina w latach 1869-1919, Warszawa 1994, s. 70-71; H. Kozińska-Witt, dz. cyt., s. 52; K. Maleczyńska, Stan badań nad historia bibliotek 


\section{Czytelnia Izraelicka}

Czytelnia Izraelicka, powołana w 1871 r., z dużym prawdopodobieńswem była pierwszą świecką czytelnią żydowską w Krakowie. Miała ona w dużej mierze cele towarzyskie, związane ze wzajemną integracją swoich członków, co zresztą wspominano w statucie Stowarzyszenia Czytelni Izraelickiej. Placówka miała jednak także bardziej ogólny cel, również zapisany w statucie, którym było „rozbudzenie ruchu i życia umysłowego w duchu ojczystym”. W tym kontekście oznaczało to polską kulturę i język. Czytelnia miała więc aspiracje wspierania integracji Żydów ze społeczeństwem większościowym. Kolejnym jej celem było kształcenie i zwiększanie poziomu wiedzy ogólnej, świeckiej. Te główne założenia utrzymały się i w kolejnych latach nawoływano członków Czytelni „do kształcenia się i do zgody z ludnością polską”4.

Dzięki zachowaniu się listy osób, które przedłożyły Namiestnictwu do zatwierdzenia statut Czytelni, wiemy nieco więcej na temat jej zaplecza społecznego. Znajdujemy wśród nich między innymi Szymona Dankowicza, który od 1868 r. pełnił funkcję kaznodziei w krakowskiej synagodze postępowej (Tempel). Bezpośrednio przed przyjazdem do Krakowa mieszkał w Warszawie, gdzie angażował się w propolską działalność patriotyczną - był m.in. uczestnikiem manifestacji poprzedzających wybuch powstania styczniowego. W Krakowie podejmował inicjatywy polonizacyjne, takie jak: udzielanie lekcji języka polskiego współwyznawcom, wygłaszanie polskich kazań czy publikowanie w tym języku. Jego udział w założeniu i pracach Czytelni Izraelickiej był więc spójny z pozostałymi obszarami działalności.

Poza Dankowiczem wśród założycieli i członków pierwszego zarządu Czytelni byli głównie przedstawiciele żydowskiej świeckiej inteligencji, w tym lekarz Michał Kaufmann i trzech studentów prawa: Zygmunt Markusfeld, Izydor Silberfeld oraz Zygmunt Zins 5 . Pozostałe osoby to: agent handlowy Joseph Weidenfeld i księgarz I.Z. Herzog. W skład kolejnego zarządu, wybranego w 1873 r., weszli m.in Jonathan Warschauer, znany lekarz, społecznik i filantrop, radca miejski i jeden z najbardziej aktywnych przedstawicieli środowiska postępowego, a także dwóch przyszłych adwokatów - Jan Albert

polskich doby zaborów oraz ich podstawa źródłowa, [w:] Z dziejów udostęniania książki w Polsce w okresie zaborów. Studia i materiały, pod red. K. Maleczyńskiej, Wrocław 1985, s. 5-36; A. Żbikowski, Czytelnia Polska Starozakonnej Młodzieży Handlowej, [w:] Polski stownik judaistyczny. Dzieje, kultura, religia, ludzie. T. 1, oprac. Z. Borzymińska, R. Żebrowski, Warszawa 2003, s. 312.

4 Statut Stowarzyszenia Czytelni Izraelickiej, Kraków 1871 (druk przechowywany w Bibliotece Jagiellońskiej), zob. też Kronika miejscowa i zagraniczna (Czytelnia izraelicka w Krakowie...), „Czas" 1877, nr 254, s. 3.

5 Stosunkowo najwięcej wiemy o Markusfeldzie, zob. P. Jasnowski, A Case Study of Radical Assimilation in Poland. The Markusfeld Family, „Scripta Judaica Cracoviensia” 2016, t. 14, s. 121-123. 
Propper oraz Józef Rosenblatt ${ }^{6}$. Warschauera, Proppera i Rosenblatta znajdziemy w zarządzie także parę lat później ${ }^{7}$.

Pomysł powołania Czytelni powstał najpóźniej na początku $1871 \mathrm{r}$. 30 stycznia tego roku w byłym ratuszu kazimierskim odbyło się spotkanie twórców inicjatywy, podczas którego przeczytano projekt statutu ${ }^{8}$. Musiał zostać wówczas przyjęty, gdyż wkrótce przesłano Namiestnictwu do akceptacji projekt datowany na 31 stycznia ${ }^{9}$. Nie ma pewności, kiedy Czytelnia rozpoczęła faktyczne funkcjonowanie (udostępnianie książek i prasy). Niewykluczone, że stało się to dopiero pod koniec grudnia 1872 r. Wówczas bowiem krakowska prasa donosiła o otwarciu czytelni przy ul. Krakowskiej $71 \mathrm{w}$ lokalu niejakiego Marguliesa $^{10}$.

\section{Odczyty}

Jednym ze środków do osiągania celów statutowych Stowarzyszenia Czytelni, czyli edukacji i ,unarodowienia" Żydów, były organizowane w jej lokalu „odczyty z dziedziny rozmaitych umiejętności”" ${ }^{11}$. Zasadniczo były one przeznaczone dla członków stowarzyszenia i innych osób, którym przyznano prawo uczestniczenia w prelekcji. Niewykluczone jednak, że na rzecz Czytelni urządzano także otwarte odczyty i wykłady, na które obowiązywały bilety wstępu. Dochody z publicznych odczytów i zabaw jako jedno z możliwych źródeł finansowania Stowarzyszenia podaje bowiem jego statut.

Według zachowanych źródeł odczyty te dotyczyły zarówno wiedzy ogólnej jak i „tematów judaistycznych”, związanych na przykład z historią Żydów. Pojawiała się także tematyka dotycząca historii Polski, na przykład uchwalenia Konstytucji 3 Maja $^{12}$. Ze źródeł nie wynika jednoznacznie, w jakim języku

6 Hanna Kozińska-Witt wśród członków zarządu Czytelni, wybranego w 1873 r. wymienia także następujące nazwiska: Zauderer, Able, Einhorn, Munk, Fischer, zob. H. Kozińska-Witt, dz. cyt., s. 161.

W 1876 r. prezesem był jeszcze Warschauer, zob. Kronika miejscowa i zagraniczna (Z Kazimierza 10go marca), „Czas” 1876, nr 59, s. 3 , w 1877 r. w tej roli znajdujemy Proppera, zob. Kronika miejscowa i zagraniczna (Czytelnia izraelicka w Krakowie...), „Czas”, 1877, nr 254, s. 3, który zapewne zastąpił Warschauera na tej funkcji po odnowieniu Czytelni. W 1877 r. członkiem zarządu był też Rosenblatt.

8 Kronika miejscowa i zagraniczna (Wczoraj odbyło się w sali ratusza Kazimierskiego...), „Czas” 1871, nr 25, s. 3.

9 Central Archive for the History of Jewish People (Jerozolima, Izrael), sygn. HM2/8934.17, List założycieli czytelni do Wysokiego Namiestnictwa z 31 I 1871.

10 Kronika miejscowa i zagraniczna (W sobote otwarta została na Kazimierzu...), „Czas” 1873, nr 1, s. 2, w notatce pisano o otwarciu lokalu na Kazimierzu w „sobotę”, czyli 28 XII 1872 r.

11 Zob. §1-2 w Statut Stowarzyszenia..., s. 3.

12 H. Kozińska-Witt, dz. cyt., s. 161; Kronika miejscowa i zagraniczna (W sobote jako rocznice ogloszenia konstytucyi...), „Czas” 1873, nr 104, s. 2. 
odbywały się wykłady. Z uwagi na założenia programowe Czytelni (wspieranie polonizacji, integracji) możemy zakładać, że przynajmniej część z nich wygłaszano po polsku. W 1877 r. w Czytelni często miewał odczyty kaznodzieja postępowy Maurycy Duschak, który języka polskiego nie znał, należy więc zakładać, że wykładał po niemiecku ${ }^{13}$.

\section{Księgozbiór}

Statut Stowarzyszenia Czytelni Izraelickiej precyzował, że instytucja ta będzie utrzymywała „,w odpowiednim lokalu” czasopisma o treści naukowej, politycznej, a w szczególności poświęcone „sprawom judaizmu”. Miano ponadto utrzymywać bibliotekę z książkami o charakterze naukowym „ze szczególnem uwzględnieniem piśmiennictwa ojczystego i żydowskiego, tak w języku hebrajskim, jak i w innych językach" $(\S 2)^{14}$.

Kolekcja książek i czasopism miała służyć przede wszystkim członkom Stowarzyszenia. Zatwierdzony w $1871 \mathrm{r}$. Statut precyzował, że do praw członków zwyczajnych należy korzystanie ze zbiorów Czytelni (czasopisma, książki) i uczestnictwo w wydarzeniach przez nią organizowanych (głównie chodziło tu zapewne o odczyty). Prawo do korzystania z Czytelni rozciągano jednak także na inne grupy, np. członków honorowych. Każdy członek zwyczajny miał ponadto prawo do wprowadzenia do Czytelni swojego gościa przez osiem następujących po sobie dni. Statut mówił także, że zarząd Stowarzyszenia może zezwolić na korzystanie z biblioteki osobom niezamożnym, których nie stać na wstąpienie do tej organizacji i tym samym płacenie składek. Korzystanie z biblioteki było w każdym przypadku bezpłatne. Członkowie Stowarzyszenia wnosili wprawdzie opłatę wpisową i składki miesięczne, podobnie jak to było w innych ówczesnych stowarzyszeniach dobroczynnych, edukacyjnych i społecznych, jednak nie pobierano opłat za korzystanie z księgozbioru. Wobec bardzo ograniczonego materiału źródłowego trudno jest ocenić, ile osób korzystało z Czytelni i w jakim stopniu była ona faktycznie otwarta dla osób z zewnątrz. Warto jednak odnotować, że w prasie z epoki została ona określona jako „publiczna” i mowa była o jej działaniu na rzecz miejscowych Żydów ${ }^{15}$. Według niektórych źródeł jednym z celów działania Czytelni miała być integracja poszczególnych odłamów

13 Kronika miejscowa i zagraniczna (Czytelnia izraelicka w Krakowie...) „Czas” 1877, nr 254, s. 3; „Gazeta Narodowa” 1877, nr 257; Kronika zagraniczna (W Krakowie za staraniem...), „Izraelita" 1877, nr 45, s. 367.

14 Statut Stowarzyszenia..., s. 3.

15 Kronika zagraniczna (W Krakowie za staraniem...), „Izraelita” 1877, nr 45, s. 367. W cytowanej wzmiance mowa jest o świeżo założonej instytucji, niemal na pewno chodziło jednak o istniejącą od 1871 r. Czytelnię Izraelicką, która odnowiła swoją działalność po okresie zawieszenia. 
społeczności żydowskiej, co pośrednio może potwierdzać jej przynajmniej częściowo otwarty charakter ${ }^{16}$.

Nie wiemy dokładnie kiedy i w jakich okolicznościach instytucja zakończyła funkcjonowanie. Jej działalność niemal od początku istnienia napotykała na pewne trudności. Już w 1873 r., a więc zaledwie dwa lata po jej powołaniu, a przypuszczalnie też $\mathrm{w}$ roku, w którym zaczęła faktycznie funkcjonować, jej prace zostały tymczasowo na kilka miesięcy zawieszone, co mogło mieć związek z panującą wówczas w Krakowie epidemią cholery ${ }^{17}$. Zapewne działała w jakiejś formie w kolejnych latach, jednak jej aktywność albo została wkrótce przerwana, albo była wyraźnie osłabiona. Już w marcu 1876 zorganizowano bowiem walne zgromadzenie, podczas którego uchwalono pobierać wpisowe i składki członkowskie, a dzięki uzyskanym środkom odnowić funkcjonowanie czytelni „nieaktywnej od dwóch lat", czyli zapewne od 1874 roku $^{18}$. Rzeczywiście, na nowo uruchomiono ją jesienią kolejnego roku (1877). Według krakowskiego „Czasu” do jej odnowienia przyczynić się miała współpraca młodzieży żydowskiej i akademickiej ${ }^{19}$. Po otwarciu Czytelnia przez jakiś czas działała bardzo intensywnie - z dużą częstotliwością organizowano w niej odczyty (raz na tydzień) dotyczące zagadnień ogólnych i tematów związanych z historią judaizmu. Wyraźnie miała także wzrosnąc liczba osób zainteresowanych jej działalnością i korzystających z księgozbioru. Pisano o tym w listopadzie 1877 r. na łamach warszawskiego „Izraelity”: „Liczba osób zwiedzających ten zakład i w czytaniu szukających zdrowego pokarmu ducha, z każdym dniem staje się coraz większą" ${ }^{20}$. Niestety nie wiemy, jakie były losy tej instytucji w późniejszym okresie; czy funkcjonowała, czy może - co bardzo prawdopodobne - wkrótce upadła.

Z nielicznych źródeł na temat Czytelni jakimi dysponujemy wyłania się obraz instytucji, która nie była stabilna i której działanie, przynajmniej w pewnych okresach, zamierało lub było bardzo ograniczone. Kilkakrotne wznawianie jej działalności po okresach upadku pokazuje jednak pewną determinację twórców tej inicjatywy. Fakt, że Czytelnia była organizacją świecką i miała częściowo otwarty (a według niektórych źródeł wręcz publiczny) charakter sprawia, że na gruncie krakowskim była inicjatywą pionierską.

\footnotetext{
16 J. Machof, Correspondenzen (Krakau, 12. Februar), „Allgemeine Zeitung des Judenthums“ 1874 , nr 12, s. $200-201$.

17 Zdaniem H. Kozińskiej-Witt, dz. cyt., s. 161 właśnie epidemia cholery była przyczyną zamknięcia Czytelni.

18 O staraniach tych donosił „Czas”: Kronika miejscowa i zagraniczna (Z Kazimierza 10go marca), „Czas” 1876, nr 59, s. 3. W marcu odbyło się zebranie, podczas którego uchwalono zbieranie wpisowego od osób chcących przystąpić do Czytelni, co miało pomóc w przywróceniu tej instytucji do życia.

19 Kronika miejscowa i zagraniczna (Czytelnia izraelicka w Krakowie...), „Czas” 1877, nr 254, s. 3 .

20 Kronika zagraniczna (W Krakowie za staraniem...), „Izraelita” 1877, nr 45, s. 367.
} 


\section{Czytelnia Starozakonnej Młodzieży Handlowej}

W listopadzie 1882 r. została w Krakowie otwarta Czytelnia Starozakonnej Młodzieży Handlowej. ${ }^{21}$ Zawiadywało nią Stowarzyszenie Czytelni Starozakonnej Młodzieży Handlowej, dla którego prowadzenie tej instytucji było głównym celem statutowym ${ }^{22}$.

Według statutu Czytelni do jej podstawowych obszarów działalności należało prowadzenie wypożyczalni książek, czytelni czasopism oraz organizowanie wykładów i odczytów. Poprzez założenie tej instytucji zamierzano: „młodzieży handlowej, po całodziennej, nużącej i monotonnej pracy, dać sposobność do przyjemnego i odpowiedniego ale też i korzystnego pod względem moralnym i intelektualnym spędzenia czasu"23.

Inicjatorem jej powołania miał być F. Silberfeld ${ }^{24}$, doktorant prawa na Uniwersytecie Jagiellońskim. Środki finansowe pochodziły z datków założycieli (Jakuba Bałabana oraz niejakiego Hirschfelda) oraz późniejszego jej prezesa, Józefa Libana ${ }^{25}$.

Według przekazów z epoki głównym impulsem do założenia Czytelni była niemożność pełnego włączenia się przez młodzież żydowską w prace istniejącej już w Krakowie Czytelni Młodzieży Handlowej - posiadającej teoretycznie „ogólny” profil, nieograniczony do przedstawicieli jednego wyznania, zdominowanej jednak przez młodzież katolicką. Jak donosił korespondent lwowskiej „Ojczyzny” początkowo młodzież żydowska zapisała się do tej czytelni i spędzała w niej czas wraz z młodzieżą katolicką: „,młodzież handlowa obu wyznań mile przepędzała wieczory, grywano wspólnie w gry rozmaite, gawędzono, czytano". Decyzja o założeniu odrębnej, żydowskiej instytucji o takich samych celach statutowych miała zostać podjęta, gdy

21 Prace przygotowawcze rozpoczęto przynajmniej w sierpniu tego roku, kiedy zorganizowano zebranie w celu uchwalenia statutu i wyboru tymczasowych władz organizacji. Odbyło się ono w salce przy synagodze postępowej w Krakowie, zob. Kronika (Kuryerek krakowski), „Gazeta Krakowska" 1882, nr 116, s. 3. O otwarciu Czytelni 28 listopada, zob. Korespondencye (Kraków w Grudniu 1882), „Ojczyzna” 1882, nr 24, s. 95. Pierwszy wieczorek został zorganizowany w niej już 2 grudnia tego roku, zob. Kronika miejscowa i zagraniczna (Wydziat stowarzyszenia), „Czas” 1882, nr 275, s. 2. Późniejsze źródła podają tę datę jako moment otwarcia Czytelni.

22 W dalszej części tekstu stosuję wymiennie zapis „Stowarzyszenie Czytelni” oraz „Czytelnia”, ale w obu przypadkach chodzi o tę samą instytucję. Warto przy tym mieć na uwadze, że organizacja faktycznej „czytelni”, czyli miejsca gdzie można czytać książki i prasę, była jednym z kilku celów statutowych tego stowarzyszenia, obok m.in. organizacji wieczorków i odczytów.

23 Kronika (Wydziat stowarzyszenia), „Ojczyzna” 1883, nr 23, s. 95.

24 Zapewne chodziło o urodzonego w Krakowie Feliksa Silberfelda, który studiował na wydziale prawa UJ od roku 1877/78, zob. M. Kulczykowski, Żydzi - studenci Uniwersytetu Jagiellońskiego w dobie autonomicznej Galicji (1867-1918), Kraków 1995, s. 403.

25 Kronika (Wydziat stowarzyszenia), „Ojczyzna” 1883, nr 23, s. 95. 
okazało się, że Żydzi nie zostali dopuszczeni do pełnienia funkcji w zarządzie tej organizacji ${ }^{26}$.

Krakowska Czytelnia Starozakonnej Młodzieży Handlowej nie była w Galicji jedyną instytucją tego typu-żydowskie organizacje o takim samym charakterze działały w ostatnich dwóch dekadach XIX stulecia także m.in. we Lwowie, Brodach, Tarnowie, Rzeszowie ${ }^{27}$. Czytelnie żydowskie były zakładane później niż podobne organizacje katolickie (bądź mające teoretycznie niewyznaniowy charakter), które w takim kształcie powstawały w Galicji przynajmniej od lat 60. XIX w. Na przykład w 1866 r. zawiązało się Stowarzyszenie Młodzieży Handlowej we Lwowie, które nawiązywało do długiej tradycji sięgającej XVII w. i Bractwa Młodzi kupieckiej we Lwowie ${ }^{28}$. Stowarzyszenia żydowskie funkcjonowały w bardzo podobnym zakresie do katolickich i miały bardzo zbliżone do nich cele statutowe, zapewne więc inspirowały się ich działalnością ${ }^{29}$.

Mimo iż impuls do stworzenia Czytelni Starozakonnej Młodzieży Handlowej wypłynął z krakowskiego środowiska żydowskiego, w kolejnych latach posiadała ona bliskie związki ideowe z lwowskim stowarzyszeniem Agudas Achim (Przymierze Braci). Było ono aktywne od początku lat 80. XIX w. stawiało sobie za cel polonizację galicyjskiego żydostwa i wspierało jego integrację z chrześcijańskim społeczeństwem. Realizowało swoje założenia m.in. przez rozwijanie sieci czytelń i organizowanie polskich manifestacji patriotycznych. Agudas Achim osiągnęło duże poparcie w Krakowie - to z tego miasta pochodziło najwięcej jego zamiejscowych członków. Wielu z nich było przedstawicielami środowiska Żydów postępowych, związanego z Templem. Jest bardzo prawdopodobne, że to ze Lwowa, poprzez wpływy Agudas Achim - w tym kolportaż „Ojczyzny”, organu prasowego tego stowarzyszenia, która była chętnie czytana w Krakowie - w latach 80. XIX w. płynęły do krakowskiego środowiska postępowego impulsy polonizacyjne, w postaci chociażby inspiracji do organizowania polskich obchodów patriotycznych. Jak się wydaje wyraźny polski patriotyzm Stowarzyszenia Czytelni mógł być inspirowany i podsycany wpływami lwowskimi.

\footnotetext{
26 H. ., Kraków w lutym 1892, „Ojczyzna” 1892, nr 5, s. 35-36.

27 n.-r., Tarnów dnia 10 kwietnia 1884 (sic!), „Ojczyzna” 1885, nr 8, s. 30-31; Kronika (Tow. młodzieży handlowej; Czyt. młodzieży handlowej w Brodach), „Ojczyzna” 1885, nr 24, s. 95-96; Kronika (Brody, w grudniu 1885), „Ojczyzna” 1886, nr 1, s. 3; Kronika (Z Brodów donosi nam), „Ojczyzna” 1888, nr 10, s. 77; Kronika miejscowa i zamiejscowa (Lokal czytelni), „Unia: dwutygodnik ekonomiczno-społeczny” 1885, nr 14, s. 5; n.-r. Tarnów, dnia 26 kwietnia 1886, „Ojczyzna” 1886, nr 11, s. 43.

28 Statut Stowarzyszenia Młodzieży Handlowej we Lwowie 1868, Lwów 1868, s. 3.

29 Na przykład art. 3 Statutu Stowarzyszenia Młodzieży... s. 4 mówił o prowadzeniu sali nauk i zabaw, czytelni połączonej z biblioteką oraz urządzaniu wykładów naukowych; identyczne cele miały czytelnie żydowskie.
} 
Trudno określić zasięg krakowskiej Czytelni i skalę zainteresowania jej działalnością, gdyż dane o liczbie członków Stowarzyszenia są fragmentaryczne. Sprawozdanie za rok administracyjny $1884 / 85$ podaje, że należały do niego 122 osoby (w sprawozdaniu znalazł się ich wykaz) ${ }^{30}$, jednak w prasie $\mathrm{z}$ tego samego okresu podawana jest znacznie wyższa liczba członków (320osób) ${ }^{31}$. Wobec szczupłości materiału źródłowego trudno jest omówić to zagadnienie szerzej i oszacować liczbę członków w kolejnych latach; możemy mówić jedynie o prawdopodobnej tendencji wzrostowej. Jako że lata 90 . były okresem rozwoju Czytelni (wynajęto nawet większy lokal na jej potrzeby), liczba jej członków zapewne przekroczyła tę z wcześniejszego okresu. Korespondent „Ojczyzny” pisał, że po odnowieniu Czytelni na początku lat 90. XIX w. należało do niej ,„z górą kilkaset członków"32. Niestety, nie wiadomo, czy w jakimkolwiek okresie z Czytelnią związane były także kobiety jako jej członkinie, wydaje się to jednak mało prawdopodobne ${ }^{33}$. Z pewnością uczestniczyły jednak w organizowanych przez nią wieczorkach i wycieczkach ${ }^{34}$.

Zachowane źródła pozwalają nam na zrekonstruowanie tylko dla części okresu działalności Stowarzyszenia Czytelni składu jego zarządu. Członkowie organizacji, zanim jeszcze został otwarty lokal Czytelni, próbowali namówić Alberta Mendelsburga do pełnienia funkcji prezesa, ten jednak nie przystał na ich prośbę. Pierwszym prezesem Stowarzyszenia Czytelni został J. Liban. Sekretarzem tej instytucji był Salomon Spitzer ${ }^{35}$. Po Libanie funkcję prezesa pełnili Edward Krautler - przynajmniej w 1885 r., wiceprezesem był wówczas Jakub Judkiewicz, sekretarzem Bernard Lauer, zaś skarbnikiem Józef Baschkopf oraz, z przerwą, J. Bałaban, za czasów którego Czytelnia miała przeżywać rozkwit ${ }^{36}$. W 1892 r. na stanowisku prezesa zasiadał Wilhelm Herz, wiceprezesami byli Leon Faden i znany krytyk literacki Wilhelm Feldman, sekretarzem zaś Henryk

$30 \quad$ Sprawozdanie z czynności Wydziału Stowarzyszenia Czytelni Starozakonnej Młodzieży Handlowej w Krakowie za czas od d. 1 października 1884 r. do d. 1 października 1885 r., Kraków 1885.

31 H-m., Kraków dnia 25. marca 1885, „Ojczyzna” 1885, nr 7, s. 26 korespondent podaje, że wzrost liczby członków wpłynął dobrze na finanse czytelni: „stan finansowy znacznie się polepszył, tak że czytelnia ma już byt zapewniony".

32 H.S., Kraków w lutym 1892, „Ojczyzna” 1892, nr 5, s. 35-36.

33 Niestety brakuje wykazów członków Czytelni dla całego okresu jej istnienia; jedyny znany mi dotyczy roku administracyjnego 1884/85 i nie notuje żadnej kobiety, zob. Sprawozdanie z czynności Wydziału..., dz. cyt.

34 Na wycieczki wprost zapraszano kobiety, jako osoby towarzyszące miały na nie bezpłatny wstęp („Damy w towarzystwie mężczyzn mają wstęp wolny”), zob. Kronika (W Swoszowicach), „Nowa Reforma” 1883, nr 161, s. 3.

35 Kronika (W czytelni starozakonnej mtodzieży handlowej), „Nowa Reforma” 1883, nr 94, s. 3.

36 Zapewne po raz pierwszy Bałaban został prezesem jeszcze w pierwszej połowie lat 80. XIX w.; w 1886 r. ponownie objął ten urząd by, jak donosił korespondent „Ojczyzny”, pomóc wyprowadzić Czytelnię z upadku, zob. -m.-t., Kraków, dnia 14 sierpnia 1886, „Ojczyzna” 1886, nr 17, s. 67-68. 
Suesser ${ }^{37}$. Po Herzu funkcję prezesa objął W. Feldman. Wiceprezesami byli wówczas Tadeusz Epstein i Daniel Vorzimmer, sekretarzem Adolf Deiches, zaś skarbnikiem Feliks Fromowicz ${ }^{38}$. W wyniku kolejnych wyborów, które odbyły się jesienią 1894 r., prezesem czytelni został T. Epstein, wiceprezesami H. Suesser i F. Fromowicz, sekretarzem Bernard Kupczyk, skarbnikiem zaś Ignacy Machauf ${ }^{39}$.

Lokal Czytelni znajdował się w centrum Krakowa, przy ul. Grodzkiej ${ }^{40}$. Przynajmniej od 1884 r. dysponowała ona czterema pomieszczeniami, później zaś, od lat 90. XIX w., po przeprowadzce do innego budynku mieszczącego się przy tej samej ulicy posiadała pięć pomieszczen ${ }^{41}$. Po jednym przeznaczono na czytelnię, salę wykładową oraz salę do gry w bilard. Z relacji prasowych wiemy, że lokal Stowarzyszenia został elegancko umeblowany, posiadał oświetlenie gazowe i był wyposażony w stół bilardowy (w późniejszym okresie $\mathrm{w}$ dwa) i pianino ${ }^{42}$. Funkcjonował więc de facto jak rodzaj klubu, do którego można było przyjść zagrać w bilard lub szachy, zapoznać się z najnowszą prasą, podyskutować, wysłuchać odczytu, a przy okazji wypożyczyć książkę bądź skorzystać w księgozbioru podręcznego ${ }^{43}$. Jak się wydaje na podstawie lektury doniesień prasowych na temat tej placówki, to nie księgozbiór był głównym czynnikiem przyciągającym publiczność, tylko raczej względy towarzyskie oraz bogaty program wykładów, wieczorków i innych podobnych wydarzeń.

\section{Księgozbiór: książki i czasopisma}

W ramach Czytelni funkcjonowała sekcja biblioteczna, której zadaniem było dbanie o księgozbiór i wypożyczanie książek. Funkcję bibliotekarza,

37 H. S., Kraków w lutym 1892, „Ojczyzna” 1892, nr 5, s. 35-36.

38 Lesehalle der israelitischen Handelsjugend in Krakau, „Sprawiedliwość“ 1894, nr 6, s. 3. Poza nimi w skład zarządu weszli wówczas: Sigmund Ehrenpreis, Heinrich Falter, Heinrich Fraenkel, Hipolit Frommer, Artur Fuschs, Moritz Horowitz, Rudolf Kahane, B. Kupczyk, I. Machauf, H. Suesser, Jakub Wachtel, Jakub Wasserberg.

39 Lesshalle der israelitischen Handelsjugsnd in Krakau, „Sprawiedliwość” 1894, nr 21, s. 6. Poza nimi w skład zarządu weszli: A. Deiches, S. Ehrenpreis, Stanisław Eichenbaum, Artur Fuchs, Bernard Gross, Jakub Kaufler, Adolf Kahane, Adolf Luster, Ferdinand Wachtinger, Sigismund Wachtel oraz Salomon Wechsler.

40 Kronika (Czytelnia starozakonnej młodzieży handlowej), „Nowa Reforma” 1883, nr 161, s. 3 (w lipcu 1883 r. donoszono o otwarciu siedziby przy ul. Grodzkiej 63). W 1884 r. Czytelnia przeprowadziła się na Grodzką 10 do kamienicy Michałowskiego, zob. „Ojczyzna” 1884, nr 17.

${ }^{41}$ W późniejszym okresie mieściła się w lokalu przy ul. Grodzkiej 36 i 63. Czytelnia przeprowadzała się więc zapewne dwukrotnie, zob. Kronika (Z czytelni starozakonnej młodzieży handlowej), „Nowa Reforma” 1890, nr 50, s. 2.

42 Lesehalle der israelitischen Handelsjugend in Krakau „Sprawiedliwość” 1894, nr 6, s. 3-4; Stow. izr. Młodzieży handlowej, „Sprawiedliwość” 1896, nr 21, s. 5.

43 W taki sposób korzyści płynące z członkostwa prezentowano zresztą na łamach prasy, zob. Stow. izr. Młodzieży handlowej, „Sprawiedliwość” 1896, nr 21, s. 5. 
przynajmniej w połowie lat 80 . XIX w., pełnił Daniel Reiner. Ze sprawozdania „sekcyi bibliotecznej”, jakie przygotował w 1885 r. wiemy, że w tym roku podjął pewne prace porządkowe i ulepszające funkcjonowanie biblioteki - uporządkował księgozbiór, rozpoczął prace ewidencyjne (założył księgę „spisową" i „ewidencyjną”), a także oprawił kilkadziesiąt książek. Wówczas wprowadzono też stałe godziny, w których można było wypożyczać książki. Ze sprawozdania dowiadujemy się także, że w poprzednich latach pojawiały się problemy spowodowane niedoborem książek, a jednocześnie nieuporządkowaniem księgozbioru oraz nieregularnym zwracaniem wypożyczonych pozycji ${ }^{44}$. Charakter prac, o jakich wspominał sugeruje, że przed 1885 r. działalność biblioteki mogła mieć charakter po części nieformalny.

Księgozbiór Czytelni był nieduży w pierwszych latach jej działalności. Po roku funkcjonowania obejmował 140 książek, zaś w ciągu 1885 r. powiększył się o 60 pozycji. Zostały one ofiarowane przez członków Stowarzyszenia, m.in. B. Lauera i Norberta Wasserberga ${ }^{45}$. Bliższych danych dla kolejnych lat niestety nie posiadamy. W połowie lat 90 . kolekcja książek składała się z dwóch części - księgozbioru podręcznego, przeznaczonego do korzystania na miejscu, zawierającego encyklopedie i słowniki oraz z księgozbioru służącego do wypożyczania do domu ${ }^{46}$.

Wybór czasopism dostępnych w Czytelni był relatywnie duży i obejmował prasę w kilku językach, przede wszystkim polskim i niemieckim, później także w angielskim, francuskim, hebrajskim. Po pierwszym roku funkcjonowania liczba tytułów wynosiła 29, zaś dwa lata później już $43^{47}$. W latach 90. XIX w. Czytelnia nadal dysponowała ponad 40 tytułami czasopism ${ }^{48}$. W $1894 \mathrm{r}$. ich liczba wynosiła $54^{49}$. W 1885 r. około połowa czasopism, jakie prenumerowano lub jakie Czytelnia otrzymywała, była wydawana w Galicji (głównie w Krakowie i Lwowie); wśród pozostałych dominowały tytuły ukazujące się w Warszawie lub Wiedniu. Czasopisma żydowskie pozostawały w mniejszości; wśród nich były tytuły wydawane przez integracjonistów lwowskich („,Ojczyzna”, „Izraelita”) i warszawskich (,Izraelita”)

Proporcje wydatków w budżecie Stowarzyszenia Czytelni, w którym wydatki na sekcję czasopiśmienniczą znacznie przewyższały te, które przeznaczano

\footnotetext{
44 Sprawozdanie z czynności..., s. 13-14.

45 Tamże.

46 Lesehalle der israelitischen Handelsjugend in Krakau, „Sprawiedliwość” 1894, nr 6, s. 3-4.

47 Sprawozdanie z czynności..., s. 15-17 podaje pełen wykaz czasopism dostępnych w czytelni w roku administracyjnym 1884/85. Informacje te podaje też K. Samsonowska, dz. cyt.

48 H. S., Kraków w lutym 1892, „Ojczyzna” 1892, nr 5, s. 35-36.

49 Lesehalle der israelitischen Handelsjugend in Krakau, „Sprawiedliwość” 1894, nr 6, s. 3-4.

50 Podaję szczegółowe informacje akurat dla tego roku, gdyż dysponujemy sprawozdaniem Czytelni za ten rok, zob. Sprawozdanie z czynności..., s. 16. Listę czasopism dostępnych w czytelni podaje też za cytowanym sprawozdaniem K. Samsonowska, dz. cyt., s. 221-222.
} 
na bibliotekę (księgozbiór) i inne formy działalności, sugerują, że duże znaczenie miała dla niego czytelnia bieżącej prasy. Zapewne to prasa była jednym z głównych elementów, obok aspektów towarzyskich, przyciągających członków do Czytelni.

\section{Samokształcenie, integracja i inne aspekty działalności czytelni}

W lokalu Czytelni organizowano regularnie odczyty i wykłady. Spektrum poruszanych podczas nich tematów było szerokie i obejmowało zarówno zagadnienia wiążące się z działalnością zawodową członków (handel, zagadnienia ekonomiczne) i ich samodoskonaleniem, jak i tematy historyczne (dotyczące dziejów Polski i historii Żydów w Polsce), dotyczące literatury, a także innych dziedzin wiedzy (np. fizyka, biologia). W okresach, w których Czytelnia działała z dużą intensywnością - na przykład na początku 1892 r., tego typu spotkania odbywały się nawet dwa razy w tygodniu ${ }^{51}$.

Istotnym obszarem działalności Czytelni była pomoc jej członkom, polegająca zarówno na zapewnieniu im zajęć dokształcających, jak i na wsparciu materialnym oraz przy szukaniu zatrudnienia. Organizowano w niej m.in. bezpłatne dla członków kursy buchalterii, arytmetyki handlowej, korespondencji kupieckiej, stenografii oraz zajęcia językowe ${ }^{52}$.

Bardzo istotnym aspektem działalności Czytelni była integracja jej członków oraz względy towarzyskie. Mogli spędzać razem czas w jej lokalu np. grając w szachy i bilard lub podczas wieczorków tanecznych ${ }^{53}$. Podobne znaczeie miały też organizowane przez Czytelnię wycieczki, jak na przykład wyjazd do Swoszowic, z zabawami i tańcami, zorganizowany latem $1883 \mathrm{r}$. Obok niewątpliwie integracyjnego wymiaru tego przedsięwzięcia miało ono także znaczenie finansowe - udział w wydarzeniu był biletowany (stawki dla członków Stowarzyszenia Czytelni były niższe), a dochód ze sprzedaży biletów miał zostać przeznaczony na rozwój księgozbioru ${ }^{54}$. W 1889 r. Czytelnia urządziła wycieczkę do Tyńca ${ }^{55}$, a w 1891 r. na Panieńskie Skały ${ }^{56}$. Wyjazdy te miały opracowany program i obfitowały w atrakcje, takie jak tańce, loteria fantowa czy tombola. Powrót z wyjazdu na Panieńskie Skały w 1891 r. miał

51 „Kronika (Zarząd Czytelni starozakonnej), „Ojczyzna” 1892, nr 2, s. 14; H.S., Kraków w lutym 1892, „Ojczyzna” 1892, nr 5, s. 35-36.

52 Lesehalle der israelitischen Handelsjugend in Krakau, „Sprawiedliwość” 1894, nr 6, s. 3-4; Kronika (W czytelni krakowskiej), „Ojczyzna” 1885, nr 8, s. 31; H.S., Kraków w lutym 1892, „Ojczyzna" 1892 , nr 5, s. 35-36.

53 H.S., Kraków w lutym 1892, „Ojczyzna” 1892, nr 5, s. 35-36.

54 Kronika (Czytelnia starozakonnej), „Gazeta Krakowska” 1883, nr 186, s. 2; Kronika (Zapowiedziana wycieczka), „Nowa Reforma” 1883, nr 165-166, s. 4.

55 A. Żbikowski, Żydzi krakowscy..., dz. cyt., s. 70.

56 Kronika (Czytelnia starozakonnej), „Czas” 1891, nr 174, s. 2. 
się odbyć z muzyką i pochodniami, zapowiadano także pokaz sztucznych ogni na Błoniach ${ }^{57}$.

Pod koniec lat 80. XIX w. w Czytelni powstał męski chór, którym dyrygował kantor synagogi postępowej J. Fischer. Zespół uświetniał swoimi występami organizowane $\mathrm{w}$ niej wieczorki i uroczystości, a także promował śpiew wśród jej członków ${ }^{58}$.

Czytelnia jako instytucja przejawiała zaangażowanie społeczne organizując kilkakrotnie zbiórki na cele dobroczynne i społeczne, na przykład na zakup książek i odzieży dla ubogich uczniów czy na weteranów ${ }^{59}$.

\section{Wieczorki patriotyczne}

Jednym z najbardziej widocznych (bo szczegółowo relacjonowanych $\mathrm{w}$ prasie $\mathrm{z}$ epoki) przejawów działalności Czytelni były organizowane przez nią kilka, a w latach 90. nawet kilkanaście razy do roku wieczorki muzyczno-literackie ${ }^{60}$. Wiele $\mathrm{z}$ nich miało charakter okolicznościowy i zostało urządzonych z okazji polskich rocznic narodowych, takich jak święto Konstytucji 3 Maja, rocznice powstania listopadowego i styczniowego. Wieczorki często upamiętniały polskich bohaterów narodowych (np. Tadeusza Kościuszkę) oraz pisarzy (najczęściej Adama Mickiewicza, Juliusza Słowackiego, Józefa Ignacego Kraszewskiego, ale także np. Zygmunta Miłkowskiego). Miały propolski, patriotyczny charakter. Nierzadko zdarzało się, że spełniały funkcję nieformalnej kontynuacji uroczystości patriotycznych, jakie odbywały się wcześniej tego samego dnia w synagodze postępowej (Tempel), w której regularnie organizowano nabożeństwa z okazji polskich rocznic narodowych ${ }^{61}$.

Na podstawie wzmianek prasowych, w których relacjonowano wieczorki, możemy wskazać na ich typowe, powtarzalne elementy - na przykład wstępny odczyt popularyzatorski, wspólna deklamacja utworów poetyckich lub ich odczytanie, część muzyczna z grą na instrumencie i wspólnymi śpiewami bądź solowym popisem wokalnym. Dla przykładu, wieczorek mickiewiczowski zorganizowany w listopadzie 1890 r. miał następujący przebieg: słowo wstępne na temat twórczości Mickiewicza zakończone „wezwaniem inteligentnej

\footnotetext{
57 Tamże.

58 Wratysław Lech, Listy krakowskie XVIII, „Ojczyzna” 1889, nr 7, s. 55.

9 Kronika (W czytelni młodzieży handlowej), „Nowa Reforma” 1883, nr 272, s. 2.

60 Np. od października 1895 do października 1896 r. odbyło się 12 wieczorków, zob. Stow. izr. Młodzieży handlowej, „Sprawiedliwość” 1896, nr 21, s. 5.

${ }^{61}$ Więcej na temat tej współpracy i wieczorków patriotycznych, zob. A. Maślak-Maciejewska, Wydarzenia patriotyczne organizowane w synagodze Tempel w Krakowie, [w:] Synagoga Tempel i środowisko krakowskich Żydów postępowych, pod red. M. Galasa, Kraków-Budapeszt 2012, s. 103128.
} 
młodzieży żydowskiej do podjęcia haseł przez wieszcza rzuconych i do pracy nad unarodowieniem izraelitów" (Ignacy Suesser), trio Charlesa Augusta de Bériota, zbiorowa deklamacja trzeciej części Dziadów, śpiew solowy (Dattelbaum), gra na cytrze (L. Berger), deklamacja Reduty Ordona (H. Suesser), pieśni chóralne pod batutą J. Fischera ${ }^{62}$. Inny wieczorek, poświęcony Juliuszowi Słowackiemu, zorganizowany w 1897 r. otwarto krótkimi prelekcjami na temat kobiet w życiu wieszcza oraz jego śmierci, a następnie odbyła się artystyczna deklamacja fragmentów utworu Mindowe. Król litewski, a także Ojca zadżumionych i Hymnu o zachodzie stońca. Pomiędzy deklamacją zaprezentowano utwory muzyczne związane z twórczością Słowackiego ${ }^{63}$. Podczas wieczorków poświęconych pisarzom często jednym z punktów programu był odczyt lub wykład na temat wizerunku Żydów w twórczości danego autora, który ilustrowano cytatami $z$ jego dzie ${ }^{64}$.

W zasadzie każde z tych spotkań miało charakter wydarzenia muzyczno-literackiego i zazwyczaj angażowało uczestników do wspólnego muzykowania lub deklamacji. Część z nich miała odświętny charakter, co było podkreślone wystrojem sali. Wieczorki miały na celu przybliżenie uczestnikom przebiegu i znaczenia danego wydarzenia historycznego lub twórczości pisarza, którego rocznicę śmierci bądź urodzin właśnie obchodzono. Przede wszystkim były jednak spotkaniami towarzyskimi wypełnionymi wspólnym muzykowaniem i czytaniem literatury. Aspekt towarzyski jest szczególnie widoczny przy okazji tych wieczorków, które nie miały patriotycznej, a przy tym uroczystego i odświętnego charakteru. W przypadku takich, mniej formalnych wydarzeń po odczycie i części muzyczno-deklamacyjnej odbywała się zabawa towarzyska wypełniona tańcami ${ }^{65}$. W latach 80 . imprezy tego rodzaju były organizowane przez sekcję literacko-muzyczną ${ }^{66}$. W następnym dziesięcioleciu istniało w Czytelni kółko dramatyczne, którego inscenizacje były prezentowane podczas spotkań ${ }^{67}$.

${ }^{62}$ Kronika (W czytelni starozakonnej), „Ojczyzna” 1890, nr 1, s. 7.

63 Stowarzyszenie izrael. młodzieży handlowej, „Sprawiedliwość” 1897, nr 8, s. 6.

64 Zob. np. Kronika (W czytelni młodzieży), „Nowa Reforma” 1883, nr 40, s. 3. - wykład o Miłkowskim, podczas którego prelegent ,wykazał zapatrywania Jeża [pseudonim Miłkowskiego] na tak zwaną «kwestię żydowską», przytoczywszy ustępy z jego powieści, w których występują Żydzi szlachetni, prawi, miłujący swą ojczyznę, następnie zachęcał słuchaczów do zaznajamiania się z dziełami jubilata i wyrazić życzenie aby szli w ślady przedstawionych tam postaci”.

${ }_{65}$ Dla przykładu w 1884/85 r. odbyły się dwa takie wieczorki. Oba rozpoczęły się odczytem B. Lauera (pt. O loterii i pożyczkach loteryjnych oraz Dlugi państwowe i znaczenie ich dla społeczeństwa), a zakończyły zabawą towarzyską, zob. Sprawozdanie z czynności..., s. 11. O podobnych imprezach mających przede wszystkim towarzyski charakter wiemy zdecydowanie mniej, niż o patriotycznych, propolskich, gdyż rzadziej wspominała o nich prasa (z uwagi na ich bardziej zamknięty charakter).

66 Zob. Sprawozdanie z czynności..., s. 9.

${ }^{67}$ Stowarzyszenie izrael. młodzieży handlowej, „Sprawiedliwość” 1897, nr 8, s. 6. 
Zdecydowana większość wieczorków odbywała się w lokalu Stowarzyszenia Czytelni, który dysponował specjalnym pomieszczeniem na ten cel. Niekiedy organizowano je także w salach krakowskich hoteli, np. Union ${ }^{68}$, Klein ${ }^{69}$ czy Sachs ${ }^{70}$.

\section{Dla kogo była Czytelnia?}

Działalność Czytelni, szczególnie w zakresie udostępniania książek i czasopism, ograniczała się przede wszystkim do członków Stowarzyszenia, którzy wnosili składki na jej utrzymanie. Nie miała więc charakteru publicznego i jak się wydaje nie była otwarta dla czytelników spoza kręgu członków.

Wśród członków Czytelni dominowali przedstawiciele stanu handlowego, czyli grupy, dla której instytucja została powołana i której miała przede wszystkim służyć. Nie była jednak programowo zamknięta na inne środowiska - każdy mógł się do niej zapisać. Szczególne znaczenie miało dla Czytelni poparcie udzielone przez młodzież akademicką we wczesnych latach działalności. Jak przyznawali sami jej twórcy zaangażowanie akademików miało ułatwić założenie instytucji ${ }^{71}$. Także $\mathrm{w}$ późniejszym okresie młodzież akademicka i handlowa współpracowały ze sobą, na przykład przy inicjatywie budowy pomnika Kazimierza Wielkiego ${ }^{72}$.

Jesienią 1884 r. podczas wyborów nowego zarządu Stowarzyszenia doszło do kontrowersji. Miało się w nim zawiązać stronnictwo skupiające kilku akademików, chcących przejąć nad nim władzę. Ta walka o władzę doczekała się bardzo interesującego portretu literackiego. Związany z Czytelnią S. Spitzer poświęcił jej utwór Też ogniem i mieczem. Jest to dowcipny wierszowany utwór parodystyczny, nawiązujący luźno do gatunku eposu rycerskiego. Kształtowanie się stronnictw w Stowarzyszeniu zostało przedstawione jako przygotowanie do bitwy, a sam przebieg wyborów do jego zarządu jako zbrojna walka rycerstwa. Utwór zawiera wiele elementów humorystycznych, operuje ironią i hiperbolą ${ }^{73}$. Informacja o sporze przy wyborach $1884 \mathrm{r}$. przebiła się do prasy - o kontrowersjach, jakie wybuchły między młodzieżą handlową a akademicką pisał na przykład korespondent lwowskiej „Ojczyzny”, popularnej wśród galicyjskich

68 Stow. izr. Młodzieży handlowej, „Sprawiedliwość” 1896, nr 21, s. 5.

69 H.S., Kraków w lutym 1892, „Ojczyzna” 1892, nr 5, s. 35-36.

Ein Mickiewicz-Abend, „Sprawiedliwość” 1894, nr 23, s. 3.

71 B. Lauer, J.H. Brunner, I. Bober, J. Binenfeld, Kraków dnia 12 grudnia 1884, Szanowna Redakcyo ,Ojczyzny'we Lwowie, „Ojczyzna” 1884, nr 24, s. 95.

72 Kronika (W sprawie pomnika Kazimierza Wielkiego), „Nowa Reforma” 1883, nr 292, s. 3.

73 S.S. [S. Spitzer], Też ogniem i mieczem. Opowieść z ostatnich dni października, Kraków 1884. Autor zadedykował publikację „Zacnym a zaprawdę zacnym członkom Czytelni Starozakonnej Młodzieży Handlowej tę chudą poezys poświęca rymopis", a dochód z jej sprzedaży przeznaczył na rzecz organizacji. 
integracjonistów ${ }^{74}$. Sam zarząd Czytelni szybko zdementował te informacje, podkreślając zasługi młodzieży akademickiej dla organizacji i powołując się na owocną z nią współpracę ${ }^{75}$. Zapewne więc konflikt miał charakter w głównej mierze personalny i nie był wynikiem głębokiego ideologicznego rozłamu w Stowarzyszeniu. Taką interpretację podsuwa nam zresztą sam utwór Spitzera, mimo elementów satyrycznych bardzo ciepły w swojej wymowie.

Słabo zainteresowana działalnością Stowarzyszenia miała być młodzież rekrutująca się z warstwy inteligencji zawodowej (np. urzędnicy). W 1892 r. krakowski korespondent wychodzącej we Lwowie „Ojczyzny”, który, jak można domniemywać, miał bliskie związki z Czytelnią, pisał, że w pierwszej dekadzie jej istnienia niewielu jej członków rekrutowało się z warstw inteligencji zawodowej i osób lepiej wykształconych:

nikt nie mógł pouczyć inteligentniejszej młodzieży nieakademickiej, że jej pierwszym obowiązkiem jest bratać się z młodzieżą niższą od siebie wykształceniem [tj. handlową], aby przez wzajemne zbliżenie się wlać w nią nowe uczucia, natchnąc ją nowymi myślami ${ }^{76}$.

O ile pewne obszary działalności Czytelni były skierowane wyłącznie do członków, to na uroczystości przez nią organizowane, takie jak wieczorki patriotyczne czy wycieczki, przychodziły także osoby, które na co dzień nie były jej członkami, w tym chrześcijanie ${ }^{77}$. Na podstawie zachowanych źródeł trudno nam jest jednak oszacować skalę tego uczestnictwa. Zdarzało się, że na łamach integracjonistycznej prasy nawoływano do szerszego kierowania podobnych wydarzeń do osób „z zewnątrz”. Wynikało to zapewne ze sposobu, w jaki Czytelnia była postrzegana - jako jedno z wyraźnych centrów akulturacji, integracji oraz polonizacji i jako potencjalny krzewiciel takich postaw wśród krakowskich Żydów:

nie od rzeczy będzie zwrócić się do wydziału Czytelni z projektem urządzenia podobnych obchodów dla szerszej publiczności żydowskiej, mianowicie zaś dla warstw, które nie należą już do «obcych», a są «jeszcze nie nasze». Święcenie pamiątek wielkich zdarzeń narodowych, czczenie pamięci bohaterów, wieszczów i myślicieli ojczystych - obchodzone przy współudziale szerszych kół wywrzeć musi pożądany i skuteczny wpływ. Zwracamy na to uwagę wydziału Czytelni nie wątpiąc, że sprawę rozważy i nie omieszka skorzystać z najbliższej sposobności, ażeby projekt ten urzeczywistnićn ${ }^{78}$.

Także korespondent „Izraelity” postulował większe otwarcie Czytelni

\footnotetext{
74 -m.-t., Kraków 12 listopada 1883, „Ojczyzna” 1884, nr 23, s. 91.

75 B. Lauer, J. H. Brunner, I. Bober, J. Binenfeld, loc. cit.

6 H.S., Kraków w lutym 1892, „Ojczyzna” 1892, nr 5, s. 35-36.

77 Np. na wycieczkę do Swoszowic przybył wiceprezes Czytelni Młodzieży Handlowej Tomaszewski, a także „wielu gości chrześcijańskiego wyznania”, zob. Kronika (Zapowiedziana wycieczka), „Nowa Reforma” 1883, nr 165-166, s. 4. Wzmianki prasowe potwierdzają, że chrześcijanie uczestniczyli także w wieczorkach patriotycznych.

78 S., Kraków, 6 listopada, „Ojczyzna” 1889, nr 22, s. 178.
} 
na szersze grupy społeczne (jak to ujmował, także na młodzież „kapotową”) ${ }^{79}$. Widział w niej możliwe miejsce kształcenia osób należących do tradycyjnych warstw społeczeństwa żydowskiego. W podobnym tonie o Czytelni - jako potencjalnym centrum polonizacji i integracji - pisano na łamach polskiej prasy codziennej ukazującej się w Krakowie. Zarówno „Czas” jak i „Nowa Reforma” chętnie donosiły o jej działalności i pisały o niej w bardzo pozytywnym tonie, wyraźnie ją popierając, czego przykładem może być następująca wzmianka:

Godzi się stwierdzić, że czytelnia ta młodzieży starozakonnej doskonale pojęła sposób cywilizowania swej braci, bardzo oświaty potrzebującej i łaknącej. Da Bóg, że przy wytrwałej pracy uda się dołożyć cegiełkę do wielkiej budowy zbratania starozakonnych Polaków z współobywatelami innych wyznań wspólną kraju miłością ${ }^{80}$.

\section{Upadek Czytelni}

Nie udało mi się ustalić kiedy placówka ostatecznie zakończyła swoje funkcjonowanie. Jak się wydaje stało się to na przełomie XIX i XX w., a przynajmniej w tym okresie jej aktywność znacznie straciła na intensywności. Należy mieć na uwadze, że właściwie od początku istnienia losy Czytelni były burzliwe i pierwsze lata jej istnienia były nie tyle okresem powolnego rozwoju, co zmagania się z trudnościami i regularnymi kryzysami. Zaledwie trzy lata po otwarciu jej twórcy przyznawali, że:

bardzo bliskie były chwile jej skonu, ale zawsze w chwili, kiedy już zadawało się, że z takim trudem, wobec tak ciężkich warunków wywalczona instytucja zasnąć miała, zjawiali się mężowie, którzy sztandar podniosłych naszych celów tem silniej dźwignęli i tonące życie Czytelni na nowo wzbudzili ${ }^{81}$.

Mimo iż sprawozdanie za ten rok (1884/85) wskazuje na relatywnie bogaty program wydarzeń oraz rozwój księgozbioru i kolekcji prasy, już kilka później miał nastąpić kolejny kryzys i upadek Czytelni ${ }^{82}$. Korespondent lwowskiej „Ojczyzny” w 1892 r. wspomniał, że przed laty - dokładnej daty nie podaje, musiało to jednak nastąpić w latach 80. XIX w. - Czytelnia upadła z uwagi na trudności finansowe i długi, które spłacano wyprzedając ruchomości ${ }^{83}$.

\footnotetext{
79 Wratysław, Kraków, w Lutym 1889 r., „Izraelita” 1889, nr 10, s. 76-77.

80 Kronika (W czytelni młodzieży handlowej starozakonnej), „Nowa Reforma” 1883, nr 213, s. 3 .

${ }^{81}$ Sprawozdanie z czynności..., s. 3.

82 O złej sytuacji Czytelni w 1886 r. donosił na łamach „Ojczyzny” krakowski korespondent podpisujący się „m.-t”, Kraków w maju, „Ojczyzna” 1886, nr 11, s. 43. Kilka miesięcy później ten kryzys miał zostać częściowo zażegnany, zob. -m.-t., Kraków, dnia 14 sierpnia 1886, „Ojczyzna” 1886, nr 17, s. 67-68. Dwa lata później prasa znowu informowała o kryzysie, a następnie o upadku Czytelni, zob. Wratysław Lech, Listy krakowskie, „Ojczyzna” 1888, nr 13, s. 99; tenże, Listy krakowskie, „Ojczyzna” 1888, nr 18, s. 141-142.

83 H.S., Kraków w lutym 1892, „Ojczyzna” 1892, nr 5, s. 35-36.
} 
Poprawa jej stanu i okres pewnego rozwoju przypadły na ostatnią dekadę XIX w. ${ }^{84}$ Niewykluczone, że do odnowienia Czytelni przyczyniły się środki finansowe przekazane na jej rzecz w testamencie przez J. Warschauera (zm. 1888), który zapisał legaty kilkudziesięciu krakowskim stowarzyszeniom i organizacjom. Czytelnia znalazła się wśród kilkunastu instytucji, które otrzymały darowiznę w wysokości $300 \mathrm{złr}^{85}$.

\section{Podsumowanie}

Omówione w niniejszym artykule czytelnie miały kilka istotnych cech wspólnych - były związane ze środowiskiem postępowym, wyraźnie propolskie i miały świecki charakter. Istnienie tych podobieństw uzasadnia w mojej opinii traktowanie ich działalności łącznie, jako pewnego rozdziału w dziejach żydowskiego bibliotekarstwa w Krakowie.

Choć Czytelnia Izraelicka i Czytelnia Starozakonnej Młodzieży Handlowej nie były oficjalnie afiliowane przy Stowarzyszeniu Izraelitów Postępowych, to obie były bardzo silnie związane z tą organizacją. Jednym z najistotniejszych był związek osobowy. Wśród założycieli i w zarządach obu czytelni znajdowało się wiele osób, które były jednocześnie związane z synagogą postępową. W przypadku Czytelni Izraelickiej byli to m.in. J. Warschauer, S. Dankowicz, J.A. Propper i J. Rosenblatt, natomiast w przypadku Czytelni Młodzieży Handlowej m.in. J. Judkiewicz, S. Spitzer, D. Vorzimmer, J. Baschkopf, T. Epstein czy F. Fromowicz. Ograniczenie bazy źródłowej (zarówno dotyczącej obu czytelni, jak i Stowarzyszenia Postępowego) uniemożliwia niestety dokładne wyliczenie udziału procentowego postępowców wśród członków obu czytelni. Środowisko postępowe wspierało je na kilka sposobów, na przykład poprzez datki od indywidualnych osób, udostępnianie salki przy Templu, czy zaangażowanie personelu tej synagogi (kaznodzieje, kantor) w aktywności czytelń. Należy przy tym zaznaczyć, choć były one bardzo blisko i na wielu płaszczyznach związane ze środowiskiem postępowym, ich kolekcje nie pełniły funkcji biblioteki Stowarzyszenia Postępowego. Posiadało ono własny księgozbiór, o którym jednak nic więcej nie wiadomo. Jedyna wzmianka źródłowa na ten temat, którą udało mi się odnaleźć, dotyczy przekazania go Bibliotece Judaistycznej ,Ezra”, utworzonej pod koniec XIX w. ${ }^{86}$

\footnotetext{
84 Zob. Stowarzyszenie izrael. młodzieży handlowej, „Sprawiedliwość” 1897, nr 8, s. 6, gdzie pisano, że Stowarzyszenie Młodzieży Handlowej rozwija się „,szybko i w dobrym kierunku”; szczególnie chwalono działalność kółka dramatycznego.

85 O przekazaniu legatu zob. Legaty poczynione przez bł p. Dr Jonatana Warschauera, „Ojczyzna" 1889 , nr 2, s. 14-15. Przypuszczenie, że to legat J. Warschauera pozwolił Czytelni na podniesienie się po okresie upadku wysunął A. Żbikowski, Żydzi krakowscy..., dz. cyt., s. 70. Badacz uważa też, że czytelnia funkcjonowała przynajmniej do I wojny światowej, zob. tegoż, Czytelnia Polska Starozakonnej Młodzieży Handlowej, dz. cyt.

86 Sprawozdanie Wydzialu Towarzystwa biblioteki i czytelni publicznej „Esra” w Krakowie za
} 
Obie omówione w niniejszym artykule czytelnie miały otwarcie propolski charakter. Szczególnie manifestował się on w działalności Czytelni Starozakonnej Młodzieży Handlowej, która regularnie organizowała polskie wieczorki patriotyczne. Jej propolskie nastawienie przejawiało się także w innych działaniach - na przykład w 1890 r. zarząd tej organizacji zaoferował innym żydowskim stowarzyszeniom działającym we wszystkich trzech zaborach, że ugości ich delegatów na własny koszt w czasie uroczystości przeniesienia zwłok A. Mickiewicza na Wawel ${ }^{87}$. Delegaci Czytelni byli widoczni podczas organizowanych w Krakowie uroczystości patriotycznych - ich obecność w pochodach czy składane przez nich wieńce odnotowywała prasa ${ }^{88}$. W latach 90. członkowie stowarzyszenia bardzo zaangażowali się w inicjatywę wzniesienia w Krakowie pomnika Kazimierza Wielkiego, który miał stanąć na krakowskim Kazimierzu. Ostatecznie inicjatywa zakończyła się niepowodzeniem $^{89}$.

Księgozbiory obu czytelni miały charakter świecki i chociaż istnieje niewiele informacji na ich temat, wiadomo, że zawierały publikacje w językach nieżydowskich, w tym książki popularnonaukowe, a także bieżącą prasę. Obie placówki były niepubliczne, stowarzyszeniowe, jednak widać pewne ich otwarcie na całe społeczeństwo i chęć przysłużenia się szerszym grupom, wykraczającym poza ścisły krąg członków obu stowarzyszeń. Do ich doświadczeń odwoływano się zresztą w późniejszym okresie. Pod koniec XIX w. w pierwszym sprawozdaniu rocznym Biblioteki Judaistycznej „Ezra” (współzałożonej przez Stowarzyszenie Izraelitów Postępowych) - uznawanej za „pierwszą na ziemiach polskich żydowską świecką bibliotekę publiczną"90 - podkreślono, że cele Ezry są zbieżne z koncepcjami pojawiającymi się już wcześniej:

w kierunku [stworzenia instytucji krzewiącej oświatę i wiedzę judaistyczną] pewną akcyę podjęło już Stowarzyszenie Izraelitów postępowych w Krakowie, brakowało jednak pracy programowej i wielostronnej, brakowało urządzenia wszystkim członkom naszej gminy przystępnego $^{91}$.

czas od 25. października 1899 do 25. grudnia 1900, Kraków 1901, s. 4.

87 Z powodu sprowadzenia zwłok Adama Mickiewicza, „Ojczyzna” 1890, nr 13, s. 105-106.

88 Np. podczas uroczystości złożenia zwłok Mickiewicza na Wawelu delegaci Czytelni nieśli wieniec z napisem „Nieśmiertelnemu twórcy koncertu nad koncertami”, zob. Z obchodu złożenia zwłok Adama Mickiewicza na Wawelu, „Ojczyzna” 1890, nr 14, s. 109; Kronika (Czytelnię starozakonnej), „Ojczyzna” 1890, nr 15, s. 122.

${ }_{89}$ Jedyną pozostałością po projekcie jest umieszczona na obecnym gmachu Muzeum Etnograficznego (niegdyś ratusz kazimierski, później Izraelicka Szkoła Główna) tablica przedstawiająca Przyjęcie Żydów do Polski przez Kazimierza Wielkiego, ufundowana z pieniędzy zebranych na pomnik.

90 M. Biesaga, Krakowski „Naród księgi”, „Ibinacja” 2012, nr 22, s. 16; M. Rausz, Biblioteka i Czytelnia Ezra w Krakowie, [w:] Kraków-Lwów: książki-czasopisma - biblioteki, t. 7, Kraków 2005, s. 148-157.

$91 \quad$ Sprawozdanie Wydziału..., s. 3. 
Wspomnianą ,pewną akcyją” była, jak można się domyślać, działalność Czytelni Izraelickiej w latach 70. XIX w.

Przedstawione w niniejszym artykule instytucje (szczególnie Czytelnia Izraelicka), jako czytelnie świeckie i po części otwarte dla szerszych grup społecznych, miały zatem pionierski charakter. Ich działalność, mimo że relatywnie krótkotrwała, stanowi ważny rozdział w dziejach żydowskich bibliotek i czytelni na ziemiach polskich. Jest ona także istotna z punktu widzenia dziejów Żydów w Krakowie - obie czytelnie przyczyniły się bowiem do wzmocnienia grupy świeckiej inteligencji żydowskiej.

\section{Bibliografia}

Źródła

Archiwalne

Central Archive for the History of Jewish People (Jerozolima, Izrael), sygn. HM2/8934.17.

Prasa

„Allgemeine Zeitung des Judenthums“

Machof J., Correspondenzen (Krakau, 12. Februar), „Allgemeine Zeitung des Judenthums“" 1874, nr 12, s. 200-201.

„Czas”

Kronika miejscowa i zagraniczna (Wczoraj odbyło się w sali ratusza Kazimierskiego...), „Czas” 1871, nr 25, s. 3.

Kronika miejscowa i zagraniczna (W sobotę otwarta została na Kazimierzu...), „Czas” 1873 , nr 1, s. 2.

Kronika miejscowa i zagraniczna (W sobote jako rocznice ogłoszenia konstytucyi...), „Czas” 1873, nr 104, s. 2.

Kronika miejscowa i zagraniczna (Z Kazimierza 10go marca), „Czas” 1876, nr 59, s. 3.

Kronika miejscowa i zagraniczna (Czytelnia izraelicka w Krakowie...), „Czas” 1877, nr 254, s. 3.

Kronika miejscowa i zagraniczna (Wydziat stowarzyszenia), „Czas” 1882, nr 275, s. 2.

Kronika (Czytelnia starozakonnej), „Czas” 1891, nr 174, s. 2.

„Gazeta Krakowska”

Kronika (Kuryerek krakowski), „Gazeta Krakowska” 1882, nr 116, s. 3.

Kronika (Czytelnia starozakonnej), „Gazeta Krakowska” 1883, nr 186, s. 2. 
„Izraelita”

Kronika zagraniczna (W Krakowie za staraniem ...), „Izraelita” 1877, nr 45, s. 367.

Wratysław, Kraków, w Lutym 1889 r., „Izraelita” 1889, nr 10, s. 76-77.

„Nowa Reforma”

Kronika (W czytelni młodzieży), „Nowa Reforma” 1883, nr 40, s. 3.

Kronika (W czytelni starozakonnej młodzieży handlowej), „Nowa Reforma” 1883, nr 94, s. 3.

Kronika (W Swoszowicach), „Nowa Reforma” 1883, nr 161, s. 3.

Kronika (Czytelnia starozakonnej młodzieży handlowej), „Nowa Reforma” 1883, nr 161, s. 3.

Kronika (Zapowiedziana wycieczka), „Nowa Reforma” 1883, nr 165-166, s. 4.

Kronika (W czytelni młodzieży handlowej starozakonnej), „Nowa Reforma” 1883, nr 213, s. 3.

Kronika (W czytelni młodzieży handlowej), „Nowa Reforma” 1883, nr 272, s. 2.

Kronika (W sprawie pomnika Kazimierza Wielkiego), „Nowa Reforma” 1883, nr 292, s. 3.

Kronika (Z czytelni starozakonnej młodzieży handlowej), „Nowa Reforma” 1890, nr 50, s. 2.

„Ojczyzna. Organ stow. 'Przymierze Braci', 'Agudas Achim"”

Korespondencye (Kraków w Grudniu 1882), „Ojczyzna” 1882, nr 24, s. 95.

Kronika (Wydziat stowarzyszenia), „Ojczyzna” 1883, nr 23, s. 95.

-m.-t., Kraków 12 listopada 1883, „Ojczyzna” 1884, nr 23, s. 91.

Lauer B., Brunner J.H., Bober I.,Binenfeld J., Kraków dnia 12 grudnia 1884, Szanowna

Redakcyo ,Ojczyzny'we Lwowie, „Ojczyzna” 1884, nr 24, s. 95.

H-m., Kraków dnia 25. marca 1885, „Ojczyzna” 1885, nr 7, s. 26.

n.-r., Tarnów dnia 10 kwietnia 1884 (sic!), „Ojczyzna” 1885, nr 8, s. 30-31.

Kronika (W czytelni krakowskiej), „Ojczyzna” 1885, nr 8, s. 31.

Kronika (Tow. młodzieży handlowej; Czyt. młodzieży handlowej w Brodach), „Ojczyzna” 1885, nr 24, s. 95-96.

Kronika (Brody, w grudniu 1885), „Ojczyzna” 1886, nr 1, s. 3.

-m.-t, Kraków w maju, „Ojczyzna” 1886, nr 11, s. 43.

n.-r. Tarnów, dnia 26 kwietnia 1886, „Ojczyzna” 1886, nr 11, s. 43.

-m.-t., Kraków, dnia 14 sierpnia 1886, „Ojczyzna” 1886, nr 17, s. 67-68.

Kronika (Z Brodów donosi nam), „Ojczyzna” 1888, nr 10, s. 77.

Wratysław Lech, Listy krakowskie, „Ojczyzna” 1888, nr 13, s. 99.

Wratysław Lech, Listy krakowskie, „Ojczyzna” 1888, nr 18, s. 141-142.

Legaty poczynione przez bł p. Dr Jonatana Warschauera, „Ojczyzna” 1889, nr 2, s. 14-15.

Wratysław Lech, Listy krakowskie XVIII, „Ojczyzna” 1889, nr 7, s. 55.

S., Kraków, 6 listopada, „Ojczyzna” 1889, nr 22, s. 178.

Kronika (W czytelni starozakonnej), „Ojczyzna” 1890, nr 1, s. 7.

Z powodu sprowadzenia zwłok Adama Mickiewicza, „Ojczyzna” 1890, nr 13, s. 105-106.

Z obchodu złożenia zwłok Adama Mickiewicza na Wawelu „Ojczyzna” 1890, nr 14, s. 109.

Kronika (Czytelnię starozakonnej), „Ojczyzna” nr 15, s. 122. 
Kronika (Zarząd Czytelni starozakonnej), „Ojczyzna” 1892, nr 2, s. 14.

H. S., Kraków w lutym 1892, „Ojczyzna” 1892, nr 5, s. 35-36.

„Sprawiedliwość = Die Gerechtigkeit: Organ für Handel, Industrie und Angelegenheiten des öffentlichen Lebens"

Lesehalle der israelitischen Handelsjugend in Krakau, „Sprawiedliwość” 1894, nr 6, s. 3-4.

Lesshalle der israelitischen Handelsjugsnd in Krakau, „Sprawiedliwość” 1894, nr 21, s. 6.

Ein Mickiewicz-Abend, „Sprawiedliwość” 1894, nr 23, s. 3.

Stow. izr. Młodzieży handlowej, „Sprawiedliwość” 1896, nr 21, s. 5.

Stowarzyszenie izrael. młodzieży handlowej, „Sprawiedliwość” 1897, nr 8, s. 6.

„Unia: dwutygodnik ekonomiczno-społeczny”

Kronika miejscowa i zamiejscowa (Lokal czytelni), „Unia: dwutygodnik ekonomiczno-społeczny" 1885, nr 14, s. 5.

Źródła drukowane

Sprawozdanie Wydziału Towarzystwa biblioteki i czytelni publicznej „Esra” w Krakowie za czas od 25. października 1899 do 25. grudnia 1900, Kraków 1901.

Sprawozdanie z czynności Wydziału Stowarzyszenia Czytelni Starozakonnej Młodzieży Handlowej w Krakowie za czas od d. 1 października 1884 r. do d. 1 października 1885 r., Kraków 1885.

S.S. [S. Spitzer], Też Ogniem i Mieczem. Opowieść z ostatnich dni października, Kraków 1884.

Statut Stowarzyszenia Czytelni Izraelickiej, Kraków 1871.

Statut Stowarzyszenia Młodzieży Handlowej we Lwowie, [Lwów] 1868.

Opracowania

Biesaga M., Krakowski „Naród księgi”, „Ibinacja” 2012, nr 22, s. 15-16.

Halkowski H., Żydowski Kraków. Legendy i ludzie, Kraków-Budapeszt 2009.

Jasnowski P., A Case Study of Radical Assimilation in Poland. The Markusfeld Family, „Scripta Judaica Cracoviensia” 2016, t. 14, s. 111-132.

Kozińska-Witt H., Die Krakauer Jüdische Reformgemeinde 1864-1874, Frankfurt am Main 1999.

Maleczyńska K., Stan badań nad historia bibliotek polskich doby zaborów oraz ich podstawa źródłowa, [w:] Z dziejów udostępniania ksiażki w Polsce w okresie zaborów. Studia i materiały, pod red. K. Maleczyńskiej, Wrocław 1985.

Maślak-Maciejewska A., Modlili się w Templu. Krakowscy Żydzi postępowi w XIX wiekustudium społeczno-religijne, Kraków 2018. 
Maślak-Maciejewska A., Wydarzenia patriotyczne organizowane w synagodze Tempel w Krakowie, [w:] Synagoga Tempel i środowisko krakowskich Żydów postępowych, pod red. M. Galasa, Kraków-Budapeszt 2012, s. 103-128.

Rausz M., Biblioteka i Czytelnia Ezra w Krakowie, [w:] Kraków-Lwów: książki-czasopisma-biblioteki, t. 7, Kraków 2005, s. 148-157.

Samsonowska K., Żydowskie biblioteki i czytelnie w Krakowie w XIX i XX wieku, „Rocznik Biblioteki Polskiej Akademii Nauk w Krakowie" 1998, t. 43, s. 219-232.

Żbikowski A., Czytelnia Polska Starozakonnej Młodzieży Handlowej, [w:] Polski słownik judaistyczny. Dzieje, kultura, religia, ludzie. T. 1, oprac. Z. Borzymińska, R. Żebrowski, Warszawa 2003, s. 312 .

Żbikowski A., Żydzi krakowscy i ich gmina w latach 1869-1919, Warszawa 1994. 
